\title{
2. DEFORMATION PATTERNS AND TECTONIC REGIMES OF THE CÔTE D'IVOIRE-GHANA TRANSFORM MARGIN AS DEDUCED FROM LEG 159 RESULTS ${ }^{1}$
}

\author{
Jean Benkhelil, ${ }^{2}$ Jean Mascle, ${ }^{3}$ and Caroline Huguen ${ }^{2}$
}

\begin{abstract}
During the Early Cretaceous, the African and South American plates separated in their equatorial domain along wide transform zones made of a series of pull-apart basins including rifted and transform segments. The rifted Deep Ivorian Basin, and its southern border, the future Transform Margin studied during Ocean Drilling Program Leg 159, were areas of thick continental sedimentation from the latest Jurassic to Early Cretaceous. In Albian and early Cenomanian times, clastic sedimentation persisted in a progressively deepening marine environment. The newly created Côte d'Ivoire-Ghana Marginal Ridge (CIGMR) was eroded during part of the Cenomanian as a consequence of a tectonic uplift and subsequent emersion. A strong unconformity, recorded between the latest Albian and early Turonian at all Leg 159 sites, denotes a radical change in sedimentation, which became typically biogenic (shallow carbonates) during the Late Cretaceous.

The Early Cretaceous to Albian thick clastic wedge, which constitutes the CIGMR, has recorded various tectonic deformations that reflect different states of stresses successively prevailing during the marginal ridge formation. Early deformations clearly relate to synsedimentary mass sliding, water-escape structures, presumably triggered by earthquakes, and to dewatering cleavage, itself a consequence of dewatering processes. Synsedimentary listric normal faults have recorded collapses, differential sedimentary loading, and compaction. In more lithified sediments, sets of small-scale normal faults created a pattern of horst and graben microstructures denoting a period of extensional regime prior to a general tilting of strata. A complex microfaulting pattern made of reverse and normal faults, associated with asymmetric microfolds and attributed to a parallel to bedding shear, is interpreted as the consequence of a progressive tectonic uplift of the CIGMR active during Albian times.

The creation of the CIGMR thus appears to result from the combined effects of wrench tectonics and accompanying continental stretching and heating. On top of the marginal ridge, transpressive activity is well attested at Sites 960, 961, and 962, by shear faults showing vertical slickensides and associated crenulation and nascent cleavage. Below the Cenomanian unconformity, fractures are commonly filled with minerals such as calcite, kaolinite, quartz, pyrite, barite, and siderite, indicating that hydrothermal circulations mainly occurred during Albian to Cenomanian time span. The deformational history of the CIGMR may tentatively be summarized into four main stages:

1. An Early Cretaceous rifting stage, which created the rifted Deep Ivorian Basin, during which extensional synsedimentary deformations prevailed.

2. An Aptian-Albian syntransform stage during which a transcurrent activity along the rifted basin southern border lead to the formation of pull-apart basins. Incipient shear zones produced unstable conditions, and the extensional stresses were progressively vanishing to be progressively replaced by parallel to bedding shear, as a consequence of an early uplift of the CIGMR.

3. A late Albian stage that was contemporaneous with the development of flower structures and with the main uplift phase of the marginal ridge leading its emersion and subsequent erosion.

4. Turonian-Coniacian, in which shallow-water carbonates were deposited on top of the eroded ridge that started to subside progressively; subsidence persisted throughout the Cenozoic.
\end{abstract}

\section{INTRODUCTION}

According to Guiraud and Bellion (1995) the complete breakup of Western Gondwanaland was preceded by several rifting episodes spreading out from the Late Paleozoic to the Early Cretaceous times. Along the future Equatorial Atlantic margins the onset of rifting may have occurred during the Late Jurassic. Most of the sedimentary coastal basins were initiated during earliest Neocomian as a series of grabens and pull-apart basins created within rifted and transform segments of wide transform zones active between the African and South American plates. The rifted Deep Ivorian Basin and its southern border, the future Côte d'Ivoire-Ghana Transform Margin, were areas of thick continental sedimentation deposited in lacustrine and prodeltaic

${ }^{1}$ Mascle, J., Lohmann, G.P., and Moullade, M. (Eds.), 1998. Proc. ODP, Sci. Results, 159: College Station, TX (Ocean Drilling Program).

${ }^{2}$ URA-CNRS n 715 , Laboratoire de Sédimentologie et Géochimie Marines, Université de Perpignan, 66860 Perpignan, France.jb@univ-perp.fr

${ }^{3}$ UMR Géosciences Azur, BP nº48, 06230 Villefranche-sur-Mer, France. environments (Guiraud et al., 1997; Caprona, 1992). Clastic sedimentation persisted throughout the Albian and the early Cenomanian in a progressively deepening domain (transitional to open marine environments). During part of the Cenomanian, erosion was active on the newly created Côte d'Ivoire-Ghana Transform Marginal Ridge (CIGMR) as a consequence of its uplift and subsequent emersion. An unconformity, recorded between the latest Albian and early Turonian at all Leg 159 sites, denotes a drastic change in sedimentation, which became typically biogenic (shallow carbonates) during the Late Cretaceous.

It has been postulated that tectonic regimes change both in space and time during the development of rifted transform margins, (Mascle and Blarez, 1987; Basile et al., 1993) and analogue modeling (Basile, 1990; Basile et al., 1992) has tentatively shown that intersections between rifted basins and continental transforms develop as horsetail terminations during the early deformational stage. In a second stage, the principal displacement zones cut across the horsetail terminations and wrench tectonics is initiated between the two parting continents. Such an active transcurrent contact persists after final continental separation at the level of continent/ocean transform fault- 
ing. In this schematic model, transform marginal ridges are created mainly as the result of wrench tectonic uplift during the second stage.

The above model is based on the CIGMR, and before Leg 159 was partly supported by two data sets: (1) the interpretations, on seismic reflection profiles, of rotated blocks, half-grabens, folds, and "flower" structures (Basile, 1990; Basile et al., 1993) and (2) in situ observations and microstructural analysis from deep-sea dives performed along the CIGMR southern slope (Mascle et al., 1993; Benkhelil et al., 1996).

Available geophysical data consist of single-channel and multichannel seismic reflection profiles mainly from the Equamarge and Equasis surveys (Mascle and Blarez, 1987; Mascle et al., 1989; Lamarche et al., 1997), and gravity and magnetic measurements (Pontoise et al., 1990). Processing and interpretations of these data have allowed us to propose an acoustic stratigraphy, including six main units, and have shown that the basal unit was deformed under extension and strike-slip regimes (Basile et al., 1993). The crustal structure of the CIGMR and of the adjacent Deep Ivorian Basin have been worked out by Sage (1994) using wide-angle seismic data. Below the Deep Ivorian Basin the continental crust shows a standard progressive thinning toward the deep ocean. Comparable thinning of the crust characterizes the marginal ridge along an east-west section, but the continent-ocean transition, between the continental rooted ridge and the southern oceanic crust, is particularly narrow, in the order of $10 \mathrm{~km}$ (Sage et al., 1997).

The 14 dives made across the southern CIGMR slope, just a few miles south of Sites 960 and 961 (Mascle et al., 1993; Guiraud et al., 1997), have demonstrated that the entire continental slope consists of Early Cretaceous clastics, deposited in a prodeltaic environment (including local evidence of lacustrine deposits) that appears more proximal than the ones documented by drilling (Mascle, Lohmann, Clift, et al., 1996).

Synsedimentary deformations such as water-escape structures, listric microfaults, and slumps are abundant. At hand-sample scale, extensional features and sets of veins, as well as traces of shearing and folds, are similar to those observed in drilled samples. However, most of the samples exposed along the slope display well-developed cleavages rarely observed in the drilled section, and an intense brittle fracturing affects the outcrops. No evidence of gravity gliding and/or spreading has been described on the clastic rocks retrieved by diving across the slope. Metric-scale drag folds denoting a strike-slip regime were observed from place to place, and, chiefly upslope, 200- to 500$\mathrm{m}$-wide anticlines were deduced from dip measurements made during several dives.

As indicated by Mascle, Lohmann, Clift, et al. (1996), Leg 159 sites were selected chiefly to document the sedimentary pile of the Côte d'Ivoire-Ghana Transform Margin and more precisely to spatially assess the structural style, the deformation, the thermal regime and the subsidence history of this large-scale transform margin. Four drilled sites were selected near the ridge border (Site 959) and along its axis (Sites 960, 961, and 962). Site 959 was located just a few miles north of the CIGMR crest, in $2100 \mathrm{~m}$ water depth. Sites 960 and 961 were drilled on the CIGMR top at 2048 and $3300 \mathrm{~m}$ of water depth, respectively. Site 962 was located in $4650 \mathrm{~m}$ of water, on a small hill located at the transition between the main CIGMR and the eastern end of the fossil Romanche Fracture Zone (Fig. 1C). As anticipated before Leg 159, all sites bottomed into tectonically deformed sedimentary strata of Early Cretaceous age.

In this paper, we describe and explain the different deformational styles observed within the Cretaceous sedimentary pile of the CIGMR, and then attempt to analyze the microstructures in terms of successive tectonic regimes that have participated in the creation of the transform marginal ridge. The aim of this study, which takes into account previous geophysical (seismic reflection profiles) and geological (in situ observations) data, is to test the hypothesis of a fourstage evolutionary model for the Côte d'Ivoire-Ghana Transform Margin as proposed by Mascle and Blarez (1987) and later developed by Basile (1990) on the basis of experimental modeling.

\section{DEFORMATION RECORDED IN LEG 159 HOLES}

Previous seismic interpretations and later in situ observations made during deep dives have clearly shown that most of the thick sedimentary wedge, which forms the CIGMR, is deformed. A wide range of structures was observed in soft sediments and in brittle rocks (Benkhelil et al., 1996) that indicate extension and compression to strike-slip deformation. Such deformation types relate to various tectonic processes that occurred during the deposition and/or lithification of the Cretaceous sediments.

Leg 159 rock samples allow an interpretation of the succession of tectonic events that occurred from the time of deposition of basal units in the Early Cretaceous to the time of ridge uplift, in the Late Cretaceous. We first describe the sedimentary-induced deformations generated in soft sediments, and then the tectonic-related deformations, which occurred in more lithified sediments.

\section{Hole 959D}

Hole 959D documents a 1159-m-thick sedimentary column divided into five main lithologic units. Deformational structures have been observed in lithologic Unit III, mainly black shales (early Coniacian to late Paleocene) to Unit V, mainly siliciclastic sediments (Albian and potentially older). The transition between the two sequences, Unit III and Unit V, is recorded by lithologic Unit IV where the sediments are dominantly carbonaceous. Within Unit IV an unconformity is inferred, between the late Albian-Cenomanian and early Turonian, from a marked decrease in deformational structures and the occurrence of conglomeratic beds indicating the end of significant tectonic activity.

The most obvious soft-sediment deformation characterizes the deeper section of Hole 959D (1100-1159 mbsf), and consists of convolute laminations (Pl. 1, Fig. 1), slumped coarse-grained sandstones, planar laminated beds, and rip-up clasts of fine-grained sandstone. Extensional synsedimentary microfaults are occasional and more common near the hole bottom. In the lowest $500 \mathrm{~m}$ of the hole, bedding dips gradually increase to as much as $70^{\circ}$ near the bottom of the hole.

Normal faults are relatively abundant within the Upper Cretaceous section (Unit IVB and lower part of Unit III). However, a poor recovery within the underlying units may have precluded observation of more abundant fracturing. Vein infills consist of calcite, pyrite, quartz, dolomite, kaolinite, and, at depth, mostly barite, which appears to have been generated in several stages. At $1100 \mathrm{mbsf}$, vertical barite veinlets are cut by low-dipping lenticular veins and at $950 \mathrm{mbsf}$ a lens-shaped barite vein is sheared and bears slickensides on the vein surfaces.

\section{Hole 960A}

In this hole, about $250 \mathrm{~m}$ of Cretaceous sediments was recovered below a 175-m-thick Cenozoic section. The Cretaceous section has been divided into two main lithologic units (IV and V), separated by a sharp unconformity, itself characterized by fissuring, veining, and intense brecciation. Lithologic Unit IV is comprised of early Cenomanian to Turonian grainstones, associated with carbonate conglom- 


\section{A}

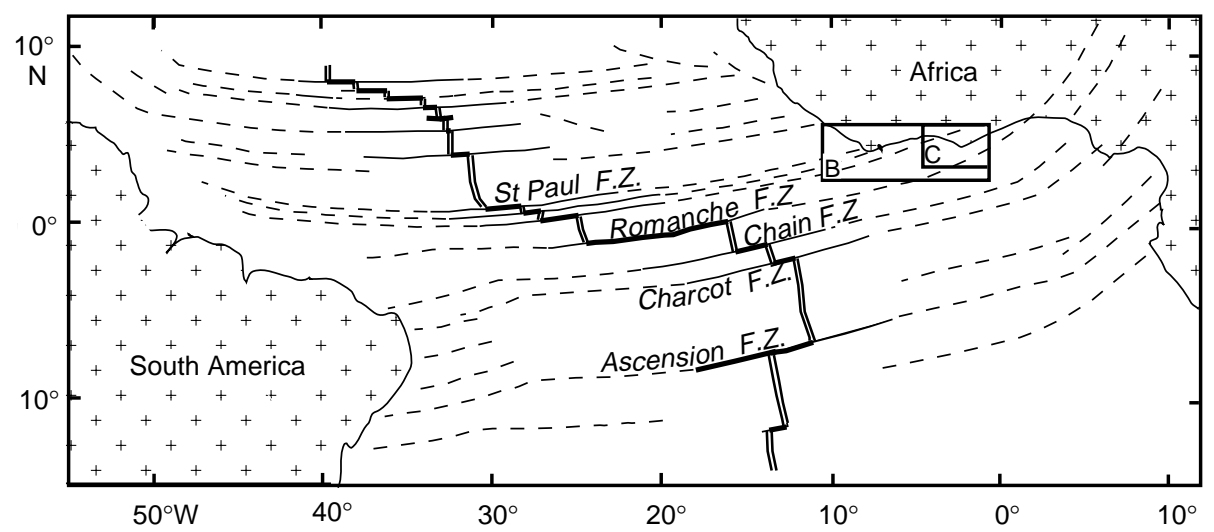

B

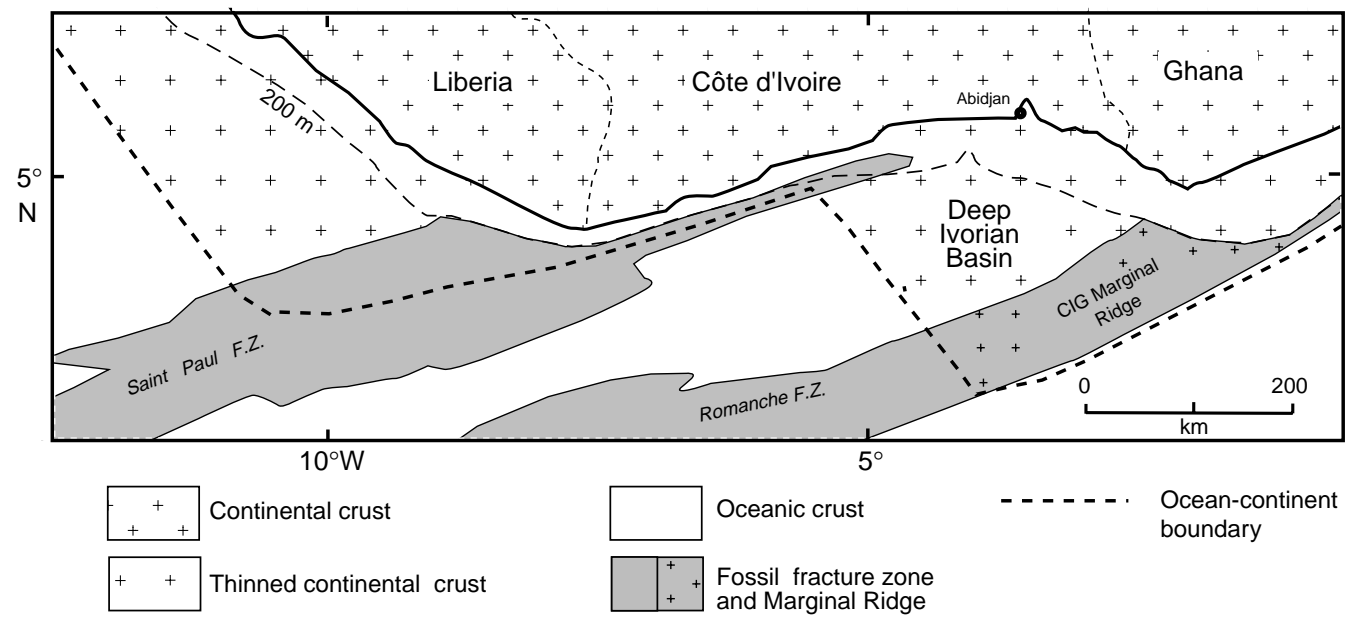

C

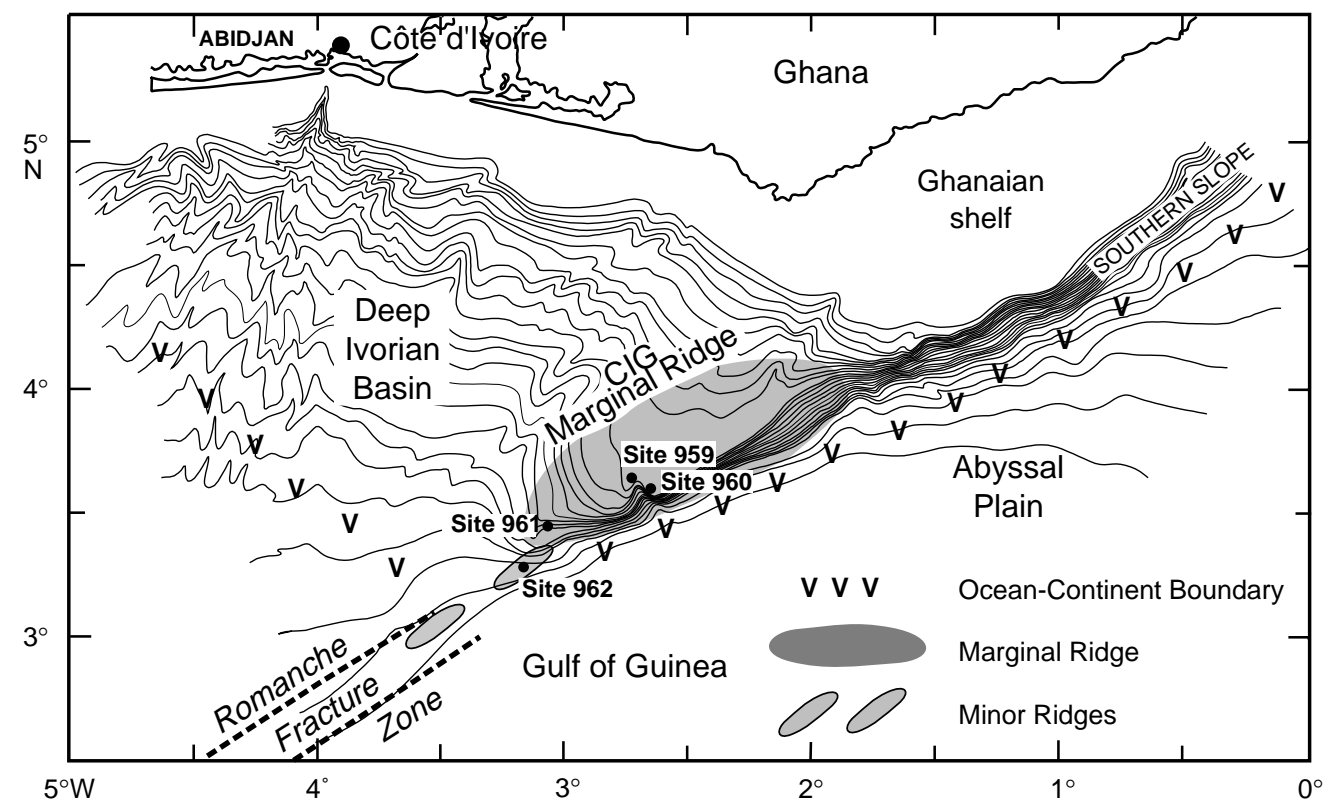

Figure 1. Geodynamic, geological, and bathymetric framework of the Côte d'Ivoire Margin. A. Geodynamic framework of the Equatorial Atlantic. Boxed regions in A are shown in detail in B and C. B. Simplified geological sketch of Côte d'Ivoire-Ghana region. C. Simplified bathymetry and main morphostructural domains of the Côte d'Ivoive-Ghana Transform Margin: solid circles show location of Leg 159 sites, the Vs indicate the probable continent-ocean transition (after Mascle et al., 1995). 
erates, and an upper Coniacian to Santonian subunit chiefly made of glauconitic claystone and hardgrounds. Unit $\mathrm{V}$ is almost entirely made of laminated sandstones, including, in the lower part of the section, probable lacustrine siltstone and claystone facies (Pl. 1, Fig. 2).

Abundant soft-sediment deformational features, such as waterescape structures, convolute bedding, and cross-laminations characterize Unit $\mathrm{V}$ where bedding dips vary from $5^{\circ}$ to $60^{\circ}$; steeper dips are observed directly below the unconformity.

Within several cores from lithologic Unit V, complex microfaulting associated with asymmetric microfolds are observed together with small "pop-up" structures (Pl. 2, Fig. 1). Fault-related microfolds, including roll-over anticlines and synclinal drag folds with normal faults and anticlines associated with reverse faults, are also noted (Pl. 2, Fig. 2). Sheared siltstones showing low dipping asymmetric microfolds associated with reverse faults (Pl. 2, Fig. 3) are also present. Horizontal slickensides, which indicate strike-slip faulting, were observed from place to place.

Below the unconformity, lithologic Unit $\mathrm{V}$ is intensely veined. Kaolinite and calcite are the most common vein filling minerals. Fissures perpendicular to bedding are infilled with calcite-cemented quartz siltstones and fine-grained sandstones. In places, however, pyrite appears closely associated with calcite in veins up to $1 \mathrm{~mm}$ wide, and is found along minor normal faults. At depth, calcite and pyrite give way to kaolinite veins, which predominate in silty claystones. Large crystals (up to $1 \mathrm{~cm}$ in diameter) of clear quartz are also found on vein surfaces in sandstone near the hole bottom.

\section{Holes 961A and 961B}

A sharp unconformity is recorded between upper Paleocene and younger sediments, and a series of alternating clayey siltstones and sandstones, about $190 \mathrm{~m}$ thick, are dated at late Albian-early Cenomanian according to palynological data at Hole 961A. Water-escape structures, sand pipes, microslumps, synsedimentary faults, and wavy-to-convolute bedding are observed throughout the entire Early Cretaceous section.

As in previous holes, bedding dips display a wide range of values. Below the unconformity, dips vary from $10^{\circ}$ to $30^{\circ}$ with a local sharp increase in laminated gray siltstones where they reach values of more than $70^{\circ}$. Association of important dips with a high degree of deformation, including vertical shears, favors a tectonic rather than a slump origin for these features.

Veining, mainly composed of calcite associated with pyrite, and locally with siderite, is common in the upper part of the laminated siltstones section. Brecciation, faulting, and microstructural evidence of shearing, however, constitute the most obvious imprints of tectonic activity in this hole.

Normal microfaults delineate numerous small tilted blocks and horst and graben microstructures. Core 159-961B-13R (Fig. 2; Pl. 1, Fig. 3) shows asymmetric microfolds due to the association of parallel shear vertical planes. Within the same core, bedding is locally cross cut by closely spaced shears, with 0.5 - to $1-\mathrm{mm}$ offsets. On thin sections these shears appear discontinuous and commonly characterized by seams of dark, clay-rich (and micaceous) material. A vertical shear band displays vertical slickensides along the walls. Adjacent blocks are affected by small-scale microfolding showing a rough crenulation as a consequence of either effective or potential shears. Asymmetric drag microfolds characterized by high-plunging axes are observed near this shear zone (Fig. 2). Comparable shear zones and arrays of normal microfaults also exist near the hole bottom.

\section{Hole 962D}

About $270 \mathrm{~m}$ of massive-to-laminated marine carbonate claystones with intercalations of silty and fine-grained sandstones of late Albian age was drilled. This unit is unconformably overlain by late

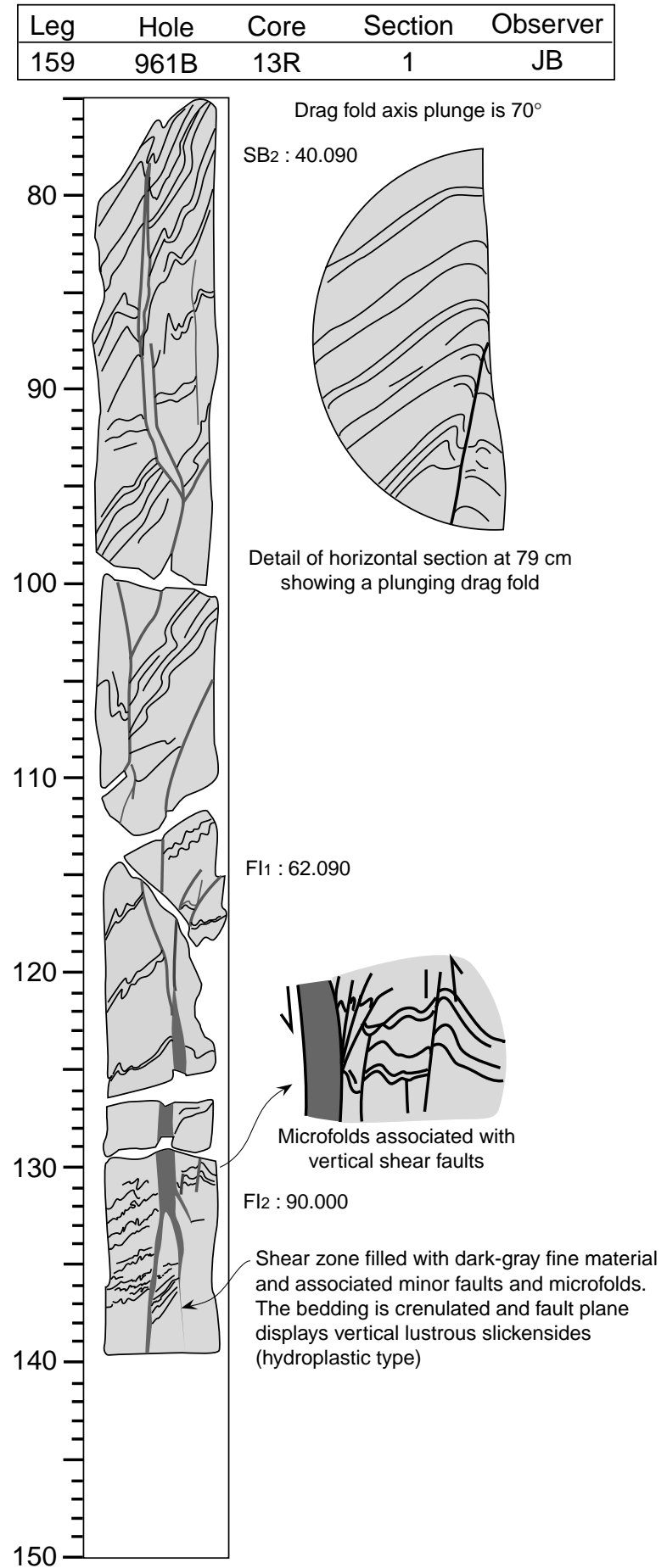

Figure 2. Sketch (visual core description) of a shear zone observed at Hole 961B (Core 159-961B-13R). Scale is in centimeters.

Albian to Cenomanian cherts and porcellanites and thin Upper Cretaceous to Holocene sediments characterized by numerous hiatuses.

Synsedimentary microfolds and slumps imply moderate sedimentary instabilities during the Early Cretaceous deposition. Almost vertical dips (up to $85^{\circ}$ ) are common within the lowest $180 \mathrm{mbsf}$ of the hole. Elsewhere, bedding dips display widely scattered values and bedding is locally highly disturbed by faulting, folding, and bioturbation. 
Calcite veins, expressed as dense networks, are ubiquitous throughout Hole 962D; they are particularly common along minor faults characterized by $1 \mathrm{~mm}$ to $0.5 \mathrm{~cm}$ of predominantly normal offsets (Pl. 1, Fig. 4). Veins commonly contain translucent sparry calcite and a pale brown micritic material, reflecting two generations of vein infill.

Faulting is abundant and tends to occur as sets rather than as isolated fault planes.

Fracturing appears as several different types, such as sharp fault planes, (open or filled by vein material), diffuse shear zones, and breccia. Normal faults may occur as conjugated sets formed prior to tilting (Pl. 1, Fig. 4). Fractures related to horizontal compression are common and generally consist of reverse faults occurring as sets or in association with asymmetric small drag folds (Pl. 3, Fig. 1). Shallow dipping shear zones are observed, or inferred, since slickensided planes bounding lens-shaped bodies were identified in disturbed parts of the cores.

Direct evidence for strike-slip faulting remains scarce. However, steeply dipping microfaults showing both normal and reverse senses of motion may be taken as indications of strike-slip motion. Strikeslip components are also attested by low pitching slickensides on vertical faults.

Folds represent one of the common structural features detected downsection from the unconformity to the hole bottom. Although their morphology indicates deformation occurring at different stages of sediment lithification, their tectonic origin is well attested by their frequent association with reverse faults. For example, a slightly asymmetric microfold has resulted in a pop-up structure (Fig. 3; Pl. 2, Fig. 1) as a consequence of a two-stage evolution (Benkhelil et al., Chap. 3, this volume).

\section{INTERPRETATION OF STRUCTURAL RECORDS}

The different microstructures described above are indicative of two different types of rheology: gravity driven pre-lithification features and tectonically generated structures.

Water-escape and sand-pipe features have obviously been created in water-rich sediment, and may have been triggered by earthquakes (Alexander, 1987; Guiraud et al., 1997). Synsedimentary faulting reflects differential sedimentary loading and burial stages, while slump microfolds and convolute laminations indicate slope instabilities. All

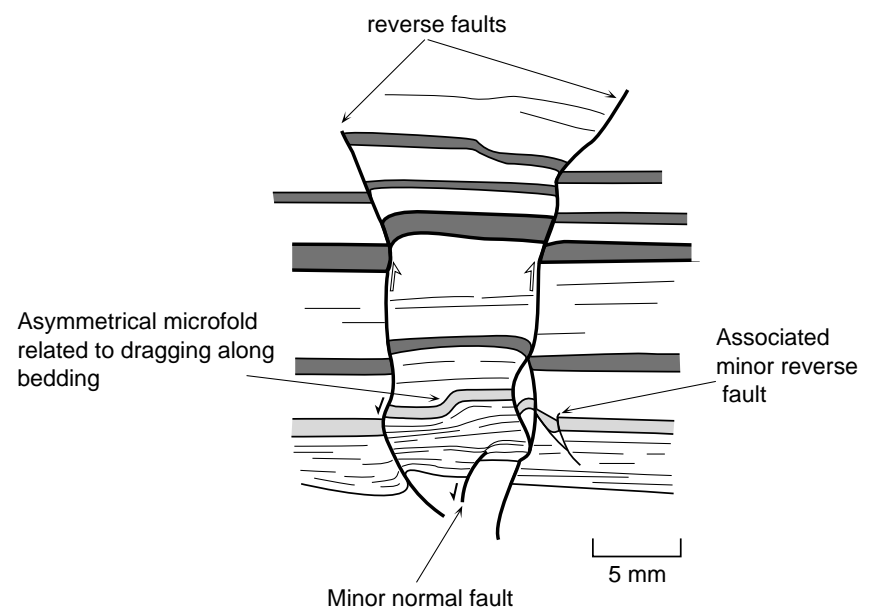

Figure 3. Sketch of a pop-up structure (Pl. 2, Fig. 1) with asymmetric drag fold and minor normal fault. First motion along the two main faults forming a small graben structure was normal (black arrows). A second reverse motion (white arrows) resulted in a pop-up structure (Sample 159-960A-55R-1, $139-141 \mathrm{~cm})$. together these synsedimentary microstructures imply unstable depositional environments where gravitational detachments and synsedimentary remobilizations were probably activated by tectonics.

Synlithification deformation such as faulting, veining, and folding, detected in Lower Cretaceous sediments from Sites 960, 961, and 962 may have resulted either from extension, shearing, and strike slip or from gravity gliding and/or spreading (Schack Pedersen, 1987; Benkhelil et al., Chap. 3, this volume).

Extension is well attested by occurrence of sets of conjugated normal faults resulting in series of micrograbens and horsts. Such an extensional activity is well expressed in Sites 960, 961, and 962 on the CIGMR axis, and less pronounced at Site 959 near the CIGMR border.

The close association between vertical shear planes, microfolding, crenulation, and nascent cleavage, particularly well recorded at Site 961 , is a clear indication of shearing. In most cases, the motion responsible for the shear zones, also detected at Site 962, is vertical as indicated by high pitching slickensides along fault planes. However, scarce evidence of horizontal strike slip is observed from place to place, notably at Sites 960 and 962 .

Veining is closely associated with both extensional and shear microstructures. Most of the vein mineralizations consist of calcite with accessory mineralizations such as kaolinite, pyrite, barite, siderite, and quartz. We, however, observed a peculiar distribution of the secondary mineralizations. Barite, kaolinite, and siderite appear to chiefly characterize Sites 959, 960, and 961, and we suspect that such variability may relate to local conditions in hydrothermal and sedimentary environments.

The close association seen between asymmetric microfolds, small "pop-up" structures, and normal and reverse faults in the lowermost lithologic units at Sites 960, 961, and 962 can be interpreted as the result of a deformation due to the displacement of an overlying body leading to parallel bedding shear. Such a mechanism may itself have been generated by regional uplift (Benkhelil et al., Chap. 3, this volume).

Finally, the occurrence in the same stratigraphic levels, of coeval features such as steep dips, shear-related microstructures, and gravity gliding, lead us to propose that they reflect the activities of positive flower structures generated in a transpressive setting (Fig. 4).

\section{DISCUSSION AND CONCLUSIONS}

The deformational features observed within the different Early Cretaceous sedimentary sections drilled during Leg 159 lead to the following remarks:

1. During Early Cretaceous times, sedimentation occurred in an unstable environment, particularly well supported by deformational structures in the sedimentary sections from Sites 959 and 960. Unstable sedimentary conditions persisted throughout most of the Cretaceous, but were more significant before the late Albian to early Cenomanian as evidenced by the high intensity of deformation below the mid-Cretaceous unconformity.

2. Within the deepest parts of the four sites, we observed good examples of soft-sediment extensional deformations, particularly at Site 962, which bottomed in uppermost Albian strata, but also at Sites 959, 960, and 961 in Albian, and potentially older, strata.

3. Whereas clear microstructural evidence of shearing and strikeslip faulting has been documented at Sites 960 through 962, these have not been observed at Site 959. This tends to support that most of the transcurrent tectonic activity took place in Early Cretaceous times, concentrated within the future CIGMR domain rather than along its northern border. The in situ 


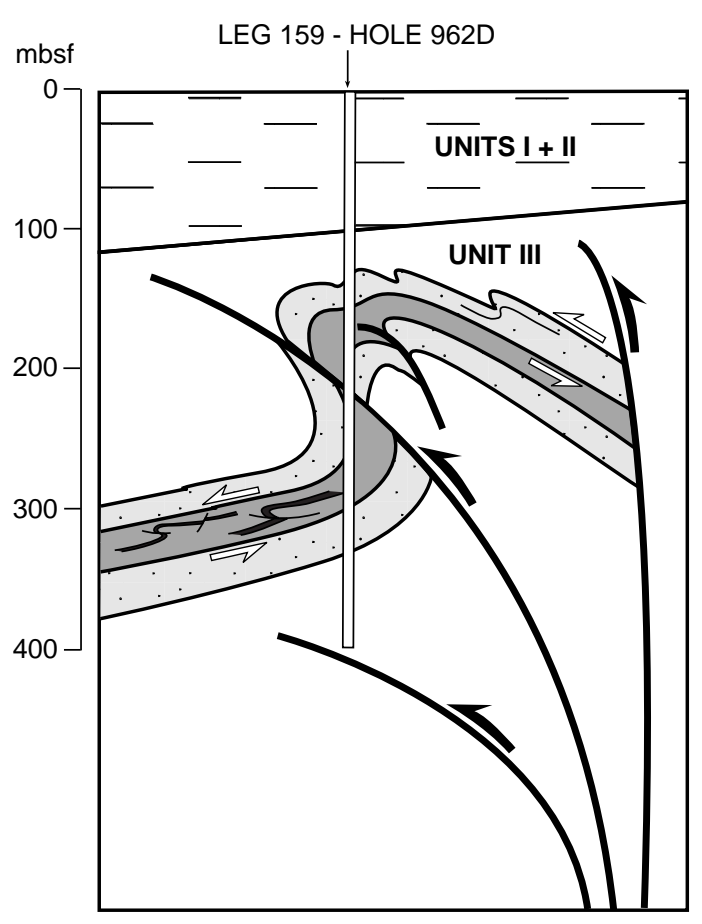

Figure 4. Interpretative section sketch of part of the CIGMR according to integration of structural data for Sites 960, 961, and, chiefly, 962. observations, previously made across the marginal ridge southern slope, confirm that folding was likely concentrated near the ridge top (Benkhelil et al., 1996).

4. Sites 960,961 , and particularly 962 show very good microstructural records of gravity gliding, a mechanism that implies local uplift. We interpret this, together with the observations of shear microstructures and drastic changes in bedding dips, as strong indicators for local transpressive tectonic activities giving rise to positive flower-type structures.

5. Deformational activity seems to have slowed, and even stopped, between the late Albian and the early Cenomanian. The presence of an unconformity, seen at Sites 960, 961, and 962 (Fig. 5), and a change in sedimentary conditions above this unconformity at Sites 959 and 960, where shallow-water carbonates were deposited during Turonian and Coniacian, argue in favor of such a change in the tectonic regime operating along the transform margin.

The above results are in fairly good agreement with the data previously gathered across the CIGMR by deep dives. In fact, most of the very accurate structural data from Leg 159 samples confirm the observations made directly in situ across the southern slope during deep dives. The only notable, but significant, difference between the two sets of data concerns the existence of a weak, but widespread, cleavage detected all along the marginal ridge southern slope. We believe that this difference may indicate that the present-day slope was, in Early Cretaceous times, part of the main wrench domain.

If correct, this hypothesis implies that the creation of folds meters to several hundred meters wide - chiefly detected upslope-may be best explained by transpressive activities generating positive flower

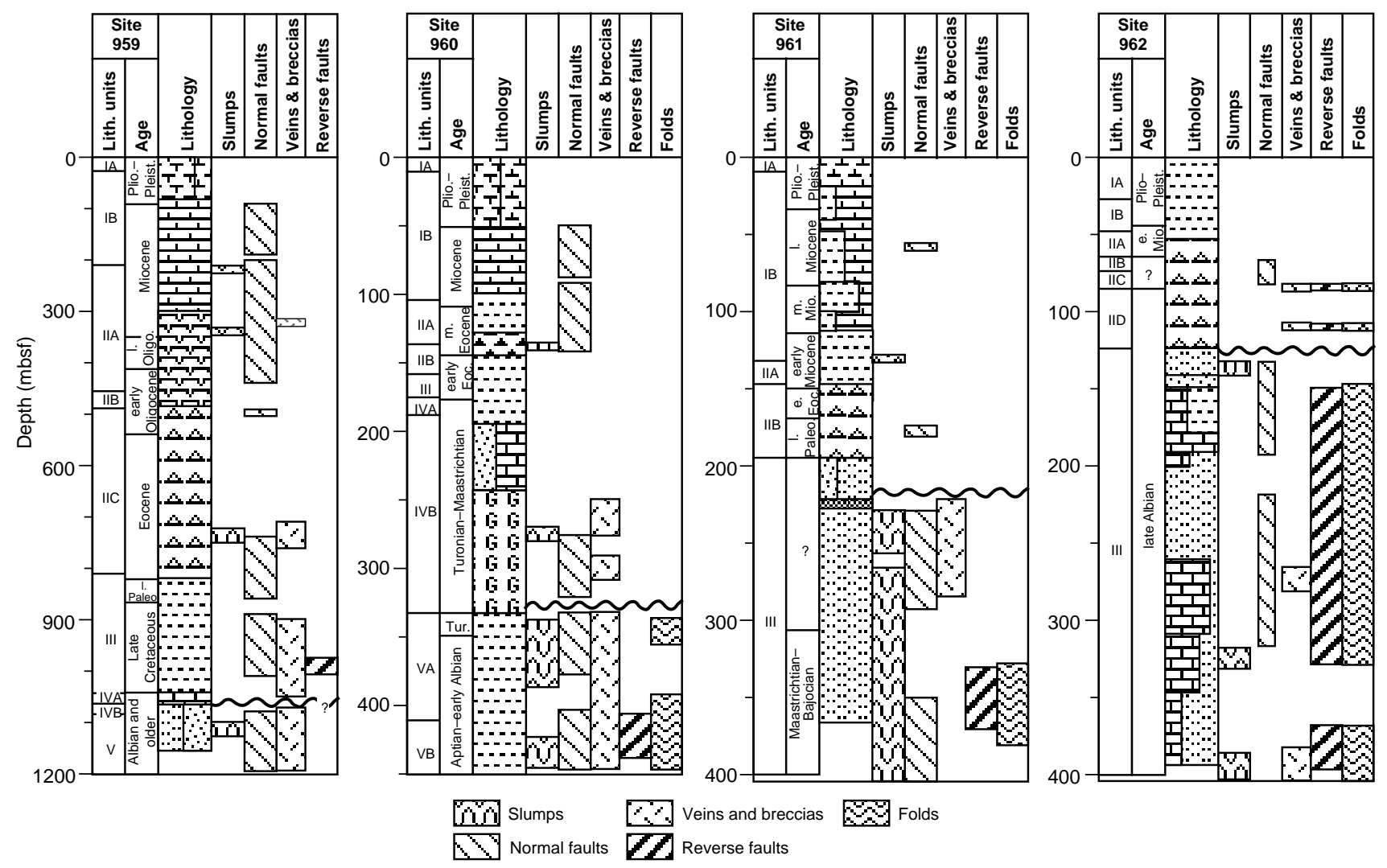

Figure 5. Synthesis of the distribution of soft sediments and tectonic-related deformation at four sites of Leg 159. Lithologic symbols are given in Mascle, Lohmann, Clift, et al. (1996). 
structures that were drilled at Sites 960, 961, and 962 (Fig. 4). Seismic reflection data, previously recorded across the western Marginal Ridge termination, clearly illustrate the occurrence of a series of positive flower structures (Basile et al., 1993).

Microstructural data from ODP Leg 159 together with in situ observations confirm and refine the interpretation of the structural and sedimentary development of the CIG Transform Margin proposed by Basile et al. (1993) (Fig. 6).

During early Albian times (and probably since the Aptian), a thick wedge of clastic sediments accumulated along two main north-south and east-west depocenters within the domain of the future transform margin (Basile et al., 1992, 1993). Along a south-north cross section (from the present-day Marginal Ridge Slope to the Deep Ivorian Basin), a thick continental sedimentary package, including lacustrine sediments, was overlain by sediments indicative of a progressively deepening depositional environment. These prodeltaic sediments now crop out along the southern slope of the ridge. The areas now occupied by the present-day ridge and its northern shoulder contain claystones and siltstones indicative of a progressively more marine environment (Site 959). Along an east-west cross section, (i.e., along the strike of the Marginal Ridge [Sites 960, 961, and 962]) and during the same time span, sedimentation became progressively more open marine concomitantly with crustal thinning and subsequent basin deepening. The Albian soft-sedimentary cover was frequently disturbed by synsedimentary deformation, probably triggered by earthquakes, affecting unstable slopes.

During late Albian times, the domain was subjected to various episodes of wrench tectonism. For example, a clear decrease in the intensity of deformation can be observed from the ridge top toward the Deep Ivorian Basin. At the same time, the Early Cretaceous sediments that now crop out along the middle to lower slope of the present-day ridge were subjected to comparatively intense shearing resulting in penetrative cleavage and associated micaceous recrystallization. Upslope, en échelon folds are evidence of transcurrent tectonic activity, while the presence on top of the ridge (Sites 960, 961, and 962) of characteristic microstructures, sharp bedding dip variations, and of gravity/gliding features, are good geological indications of probably positive flower structures generated in a transpressive regime. Extensional features were predominant along the northern shoulder of the ridge towards the Deep Ivorian Basin (Site 959).

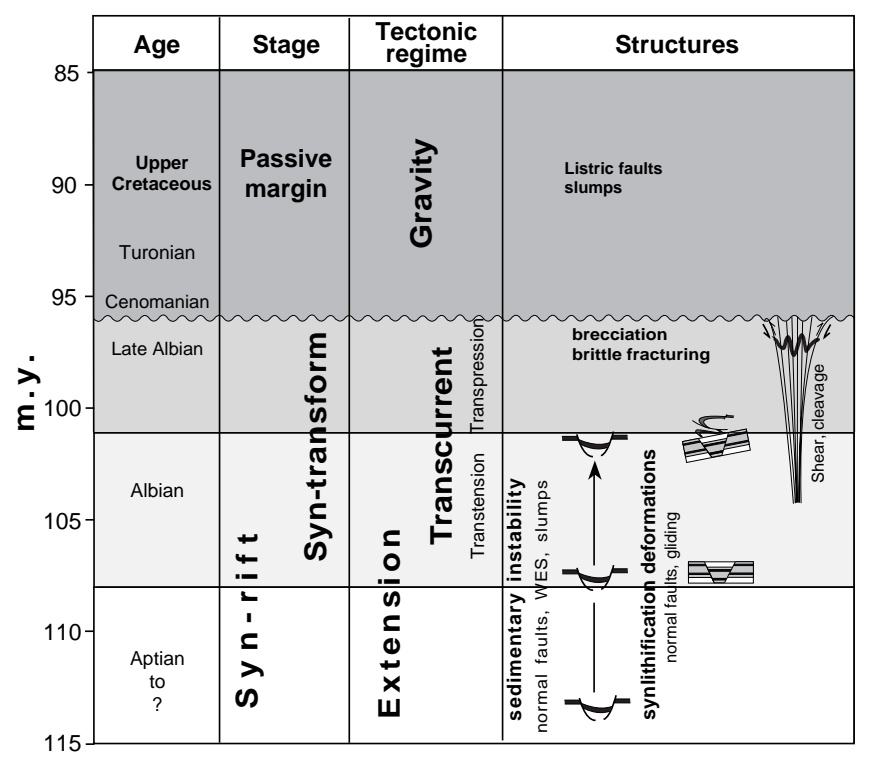

Figure 6. Postulated sequence of successive tectonic events along the CIGMR according to the ODP Leg 159 data.
In spite of comparatively poor dating because sedimentation was dominantly continental, we propose to summarize the early development of the CIG Transform Margin in four stages as follows (Fig. 7):

1. Rifting Stage. During the Early Cretaceous, a rift system formed at the emplacement of the Deep Ivorian Basin and the marginal ridge with the still-joined West African and South

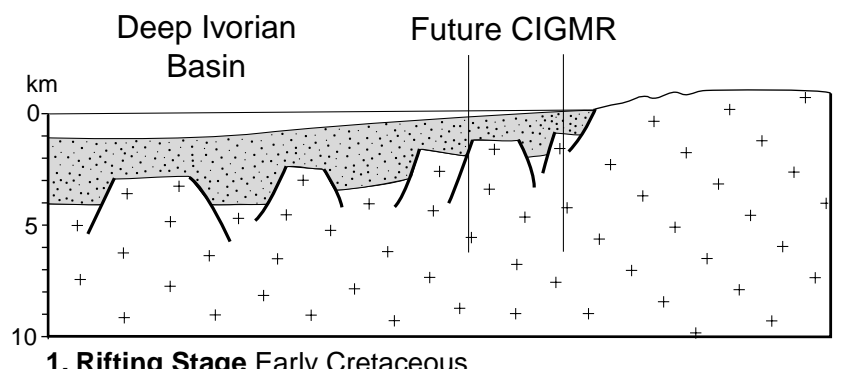

1. Rifting Stage Early Cretaceous

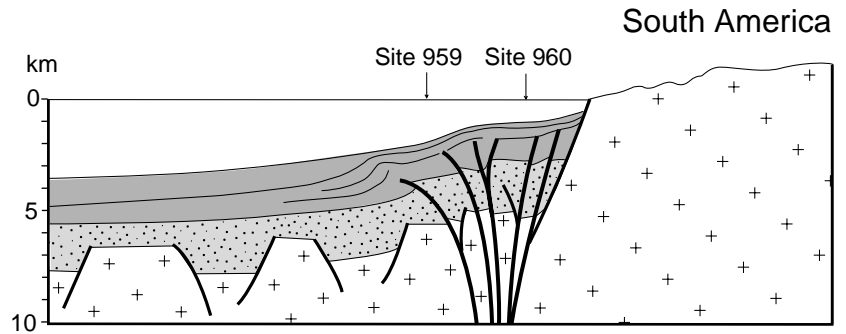

2. Syntransform Stage Aptian-Albian

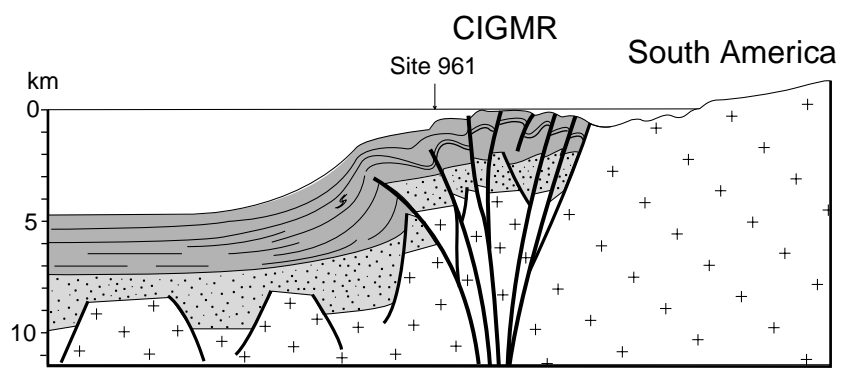

3. End of Syntransform Stage Late Albian

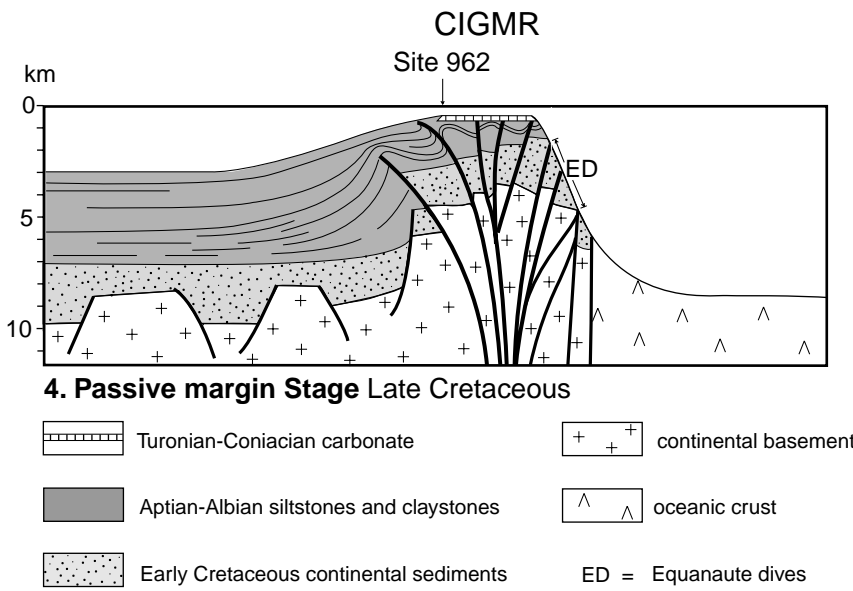

Figure 7. Interpretative schematic cross sections of the Deep Ivorian Basin and Côte d'Ivoire-Ghana Transform Margin illustrating evolution from Early Cretaceous to Late Cretaceous times. Stage $1=$ Rifting Stage; Stage $2=$ Transform Stage; Stage 3 = End of Transform Stage and Uplift; Stage $4=$ Passive Margin Stage. 
American blocks. Faulted and tilted blocks created a series of sub-basins subjected to continental sedimentation under fluvial, deltaic, and lacustrine conditions. Structural data from the oldest deposits bear evidence of synsedimentary instability resulting from general extension throughout the area.

2. Syntransform Stage. West Africa and South America split apart during the Aptian-Albian along the southern edge of the Deep Ivorian Basin producing a wide zone of wrenching with the formation of pull-apart basins. Marine influences are recorded in the siliciclastic sediments and imply a change in depositional conditions. During the latest Albian, distal calcareous turbidites (Site 962) were deposited in a deep marine ba$\sin$. Sedimentary instabilities recorded at all four ODP sites are related to wrenching motions, and characteristic structural associations indicate that the CIGMR domain was being progressively uplifted. Within the Deep Ivorian Basin, which is a segment of a divergent margin, the end of rifting is clearly recorded by an intra-Albian break-up unconformity.

3. End of Syntransform Stage. Transcurrent tectonics, responsible in part for uplift of the CIGMR as a consequence of a locally dominant transpressive regime, were active throughout Albian times and probably ended during latest Albian or early Cenomanian times. The uplift initiated during the previous stage was accentuated and the sediments were deformed by flower structures and shearing caused by wrench tectonics. The marginal ridge top was extensively eroded during part of the Cenomanian as a direct consequence of uplift and subsequent emersion.

4. Passive Margin Stage. The cessation of active transform tectonism is marked by a second distinctive unconformity recorded between the uppermost Albian and lower Turonian deposits at all Leg 159 sites. The West African and South American continental blocks were separated, and the CIGMR bordered on newly formed oceanic crust. Biogenic sedimentation consisting mostly of shallow carbonates prevailed during the Late Cretaceous over the eroded ridge top. After a period of sedimentary starvation in the Late Cretaceous, pelagic calcareous sedimentation indicates new depositional conditions, which were those of the Atlantic system. Sedimentary instabilities almost vanished after the latest Albian, and there is only scarce evidence for their occurrence from the Late Cretaceous through the Cenozoic. Structural features affecting Cenozoic deposits are exclusively extensional, attesting to the persistence of a distensive tectonic regime along the CIGMR during the Cenozoic.

\section{ACKNOWLEDGMENTS}

This is Contribution number 117 of Geosciences-Azur (UMRCNRS 6526) and contribution of LSGM (URA-CNRS 715).

\section{REFERENCES}

Alexander, J., 1987. Syn-sedimentary and burial related deformation in the Middle Jurassic non-marine formations of the Yorkshire Basin. In Jones, M.E., and Preston, R.M.F. (Eds.), Deformation of Sediments and Sedimentary Rocks. Geol. Soc. Spec. Publ. London, 29:315-324.

Basile, C., 1990. Analyse structurale et modélisation analogique d'une marge transformante: l'exemple de la marge profonde de Côte-d'lvoire-Ghana [Thèse de Doctorat]. Univ. Pierre et Marie Curie, Paris.
Basile, C., Brun, J.P., and Mascle, J., 1992. Structure et formation de la marge transformante de Côte d'Ivoire-Ghana: apports de la sismique réflexion et de la modélisation analogique. Bull. Soc. Geol. Fr., 163:207216.

Basile, C., Mascle, J., Popoff, M., Bouillin, J.P., and Mascle, G., 1993. The Côte d'Ivoire-Ghana transform margin: a marginal ridge structure deduced from seismic data. Tectonophysics, 222:1-19.

Benkhelil, J., Guiraud, M., Mascle, J., Basile, C., Bouillin, J.-P., Mascle G., and Cousin, M., 1996. Enregistrement structural du coulissage Afrique/ Brésil au sein des sédiments crétacés de la marge transformante de Côte d'Ivoire-Ghana. C. R. Acad. Sci. Ser. 2, 323:73-80.

de Caprona, G.C., 1992. The continental margin of Western Côte d'Ivoire: structural framework inherited from intra-continental shearing. Geol. Inst., A69.

Guiraud, M., Mascle, J., Benkhelil, J., Basile, C., Mascle, G., and Durand, M., 1997. Early Cretaceous deltaic sedimentary environment of the Ivory Coast-Ghana transform margin as deduced from deep dives data. GeoMar. Lett., 17:79-86.

Guiraud, R., and Bellion, Y., 1995. Late Carboniferous to Recent, geodynamic evolution of the West Gwondanian, Cratonic, Tethyan Margins. In Nairn, A.E.M., et al. (Eds.), The Ocean Basins and Margins. (Vol. 8): The Tethys Ocean, 101-124.

Lamarche, G., Basile, C., Mascle, J., and Sage, F., 1997. The Côte d'IvoireGhana transform margin: sedimentary and tectonic structure from multichannel seismic data. Geo-Mar. Lett., 17:62-69.

Mascle, J., Auroux, C., and the Shipboard Scientific Team, 1989. Les marges continentales transformantes ouest-africaines (Guinée, Côte d'IvoireGhana) et la zone de fracture de la Romanche: Campagne Equamarge II (Février-Mars 1988). Campagnes Océanographiques Françaises, 8: Brest (IFREMER).

Mascle, J., Basile, C., Pontoise, B., and Sage, F., 1995. The Côte d'IvoireGhana transform margin: an example of an ocean-continent transform boundary. In Banda, E., Talwani, M., and Thorne, M. (Eds.), Rifted Ocean-Continent Boundaries, NATO ASI Ser.: Dordrecht (Kluwer), 327-339.

Mascle, J., and Blarez, E., 1987. Evidence for transform margin evolution from the Côte d'Ivoire-Ghana continental margin. Nature, 326:378-381.

Mascle, J., Guiraud, M., Basile, C., Benkhelil, J., Bouillin, J.P., Cousin, M., and Mascle, G., 1993. La marge transformante de Côte d'Ivoire-Ghana: premiers résultats de la campagne Equanaute (Juin 1992) [The Côte d'Ivoire-Ghana transform margin: preliminary results from the Equanaute cruise (June 1992)]. C. R. Acad. Sci. Ser. 2, 316:1255-1261.

Mascle, J., Lohmann, G.P., Clift, P.D., et al., 1996. Proc. ODP, Init. Repts., 159: College Station, TX (Ocean Drilling Program).

Pontoise, B., Bonvalot, S., Mascle, J., and Basile, C., 1990. Structure crustale de la marge transformante de Côte d'Ivoire-Ghana deduite des observations de gravimétrie en mer. C. R. Acad. Sci. Ser. 2, 310:527-534.

Sage, F., 1994. Structure crustale d'une marge transformante et du domaine océanique adjacent: exemple de la marge de Côte d'Ivoire-Ghana [Ph.D. thesis]. Univ. Pierre et Marie Curie, Paris.

Sage, F., Pontoise, B., Mascle, J., Basile, C., and Arnould, L., 1997. Crustal structure and ocean-continent transition at marginal ridge: the Cote d'Ivoire-Ghana marginal ridge. Geo-Mar. Lett., 17:40-48.

Schack Pedersen, S.A., 1987. Comparative studies of gravity tectonics in Quaternary sediments rocks related to fold belts. In Jones, M.E., and Preston, R.M.F. (Eds.), Deformation of Sediments and Sedimentary Rocks. Geol. Soc. Spec. Publ. London, 29:165-180.

Date of initial receipt: 17 September 1996

Date of acceptance: 1 May 1997

Ms 159SR-006 


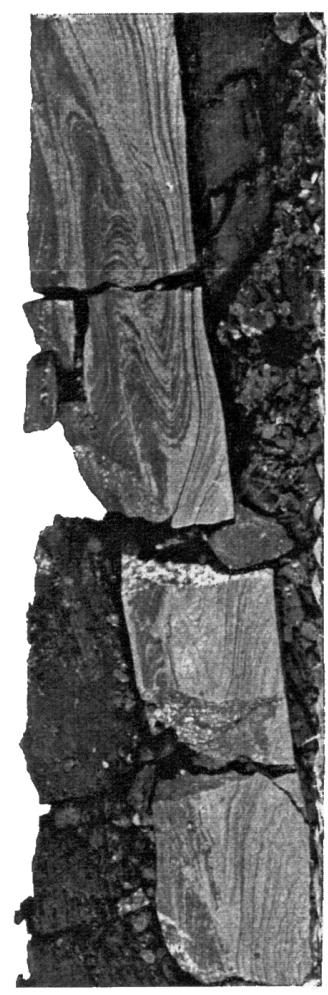

1

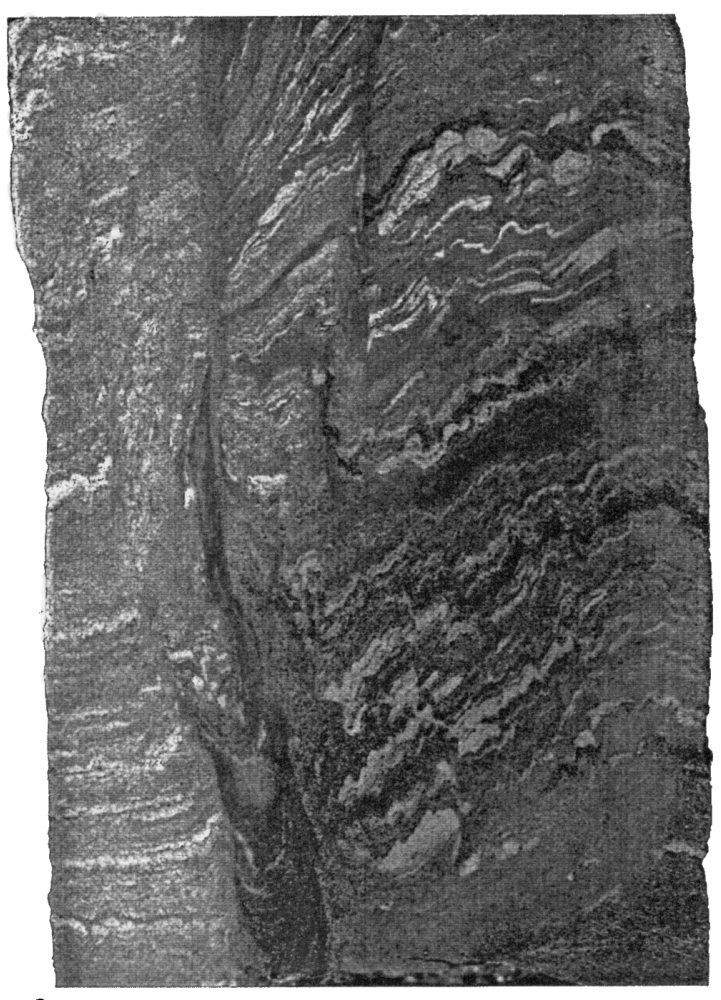

3

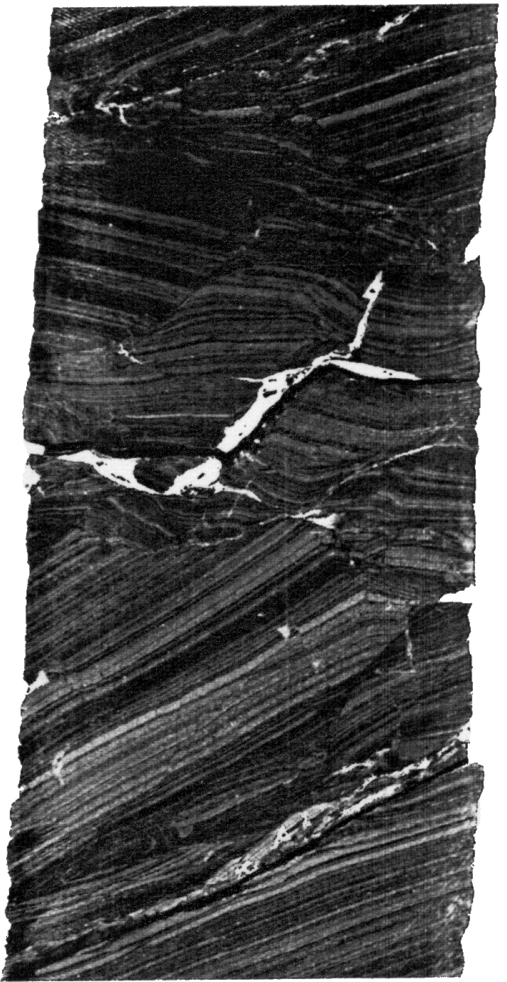

2

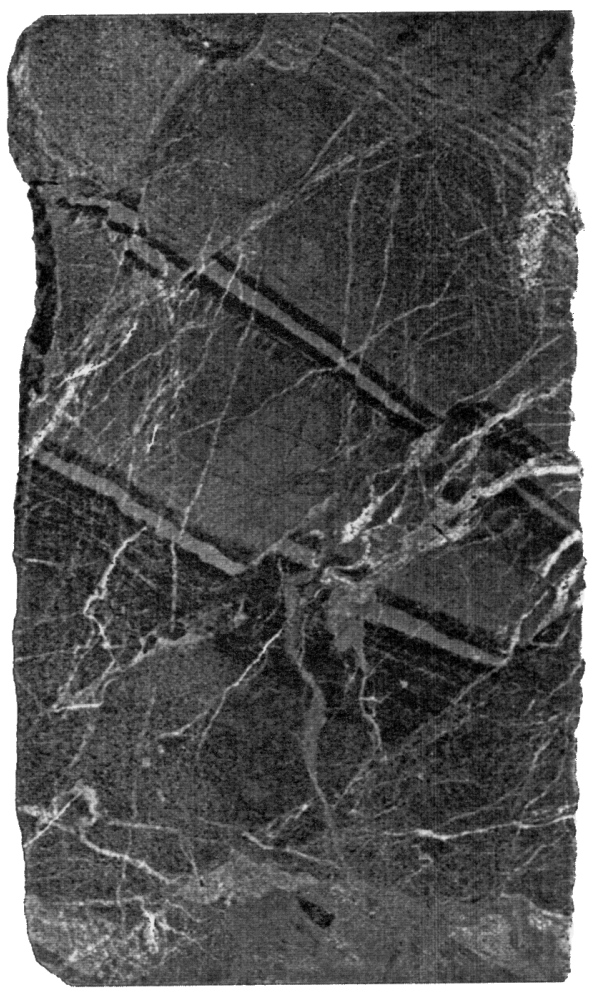

4

Plate 1. Example of soft-sediment and tectonic deformations within the Early Cretaceous section of the Côte d'Ivoire-Ghana Transform Margin. 1. Very steep dip in contourite-bedded sandstones intercalated in black shales (late Albian, Section 159-959D75R-1). 2. Example of gravity gliding-related deformation in laminated siltstones affected by kaolinite-filled fractures (Early Cretaceous, Section 159-960A-54R-3). 3. Example of shear zone characterized by crenulation and associated microfolding in lenticular bedded siltstone (late Albian-early Cenomanian, Section 159-961B-19R-1). 4. Set of conjugate normal faults prior to tilting and veining in laminated dolomitic siltstone and claystone (late Albian, Core 159-962D-6R). 


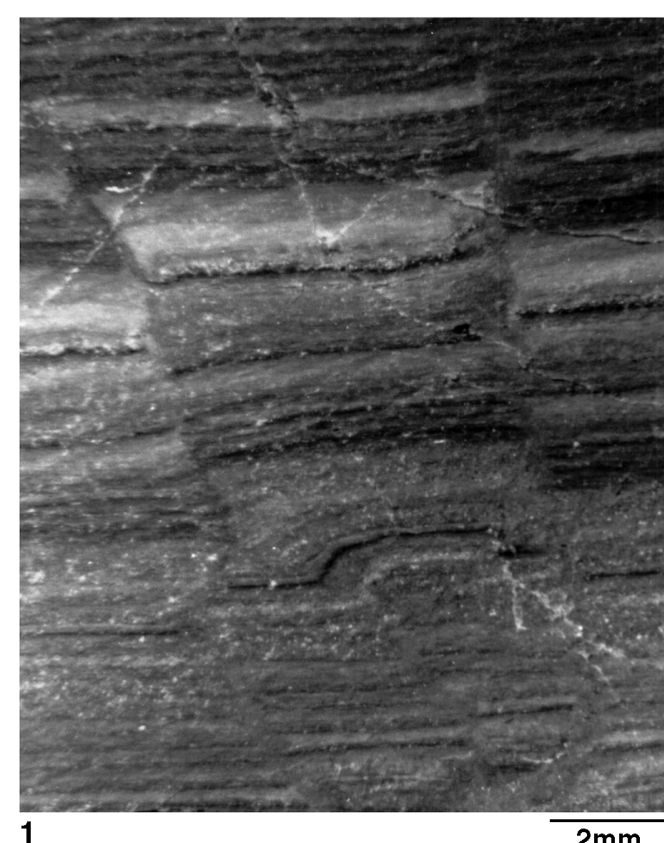

1

$2 \mathrm{~mm}$

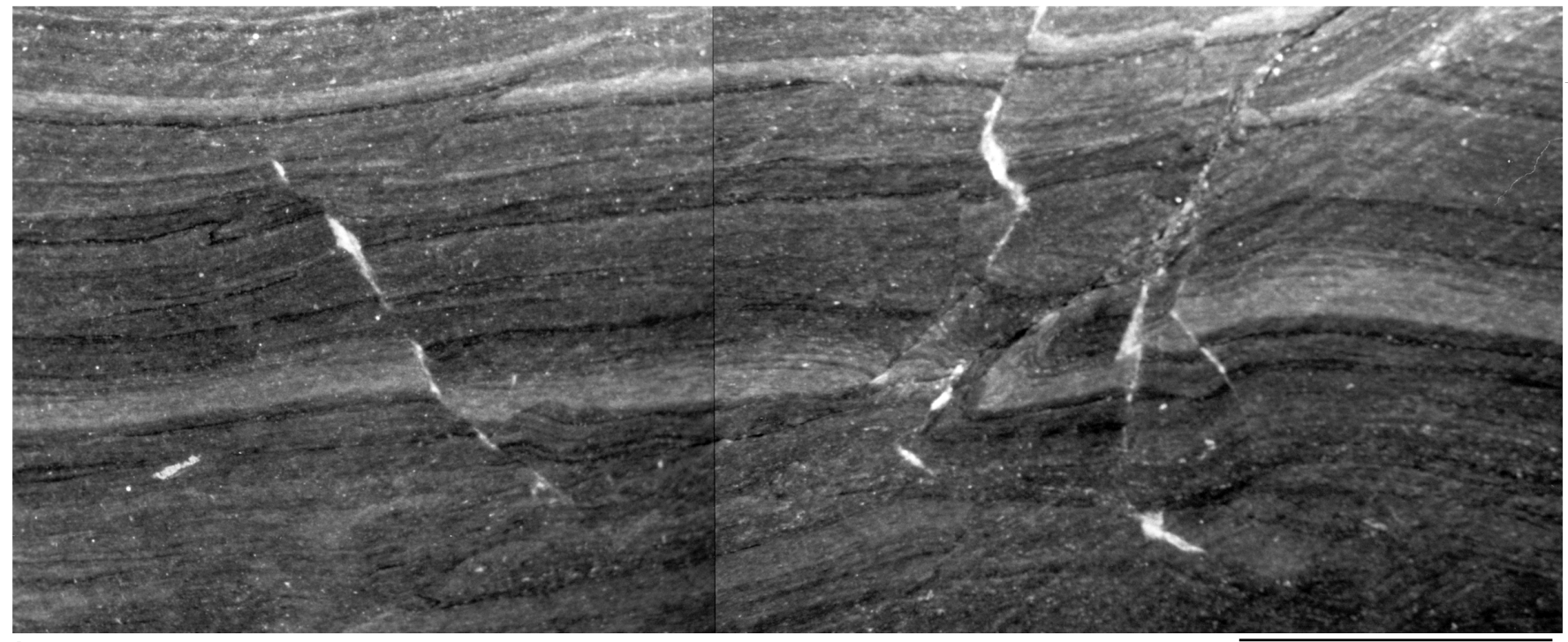

2

$1 \mathrm{~cm}$

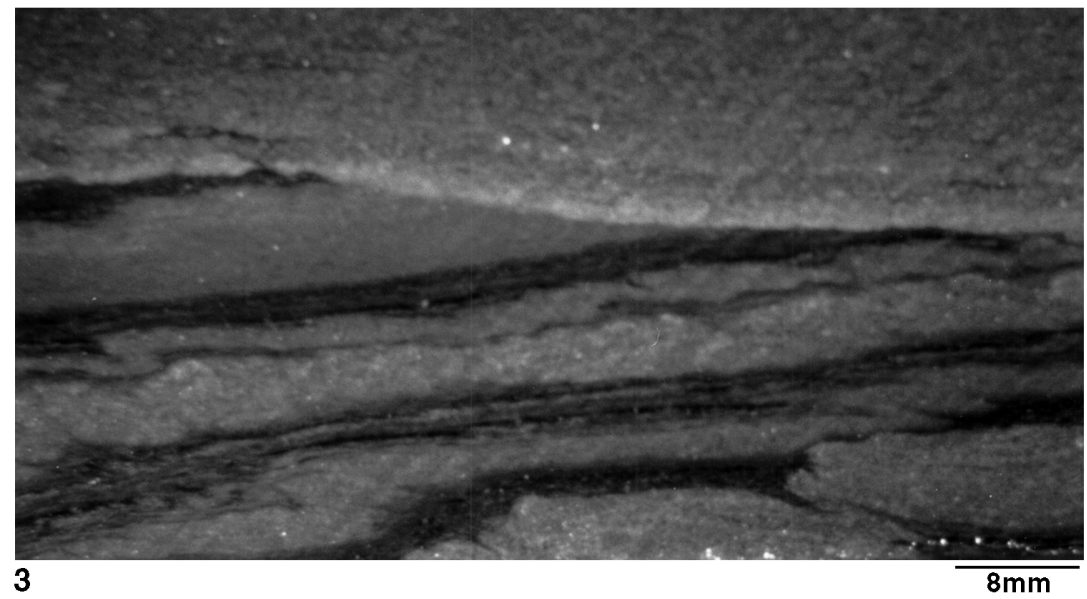

Plate 2. Example of deformation in lithologic Unit V of Hole 960A. 1. Pop-up structure with asymmetric drag fold and minor normal fault (Sample 159-960A55R-1, 139-141 cm). 2. Association of normal, reverse faults, and asymmetric microfolds resulting from gravity gliding (Sample 159-960A-54R-3, 31-35 cm). 3. Shear slump with asymmetric microfolding and associated reverse faults (Sample 159-960A-59R-2, 60-62 cm). 

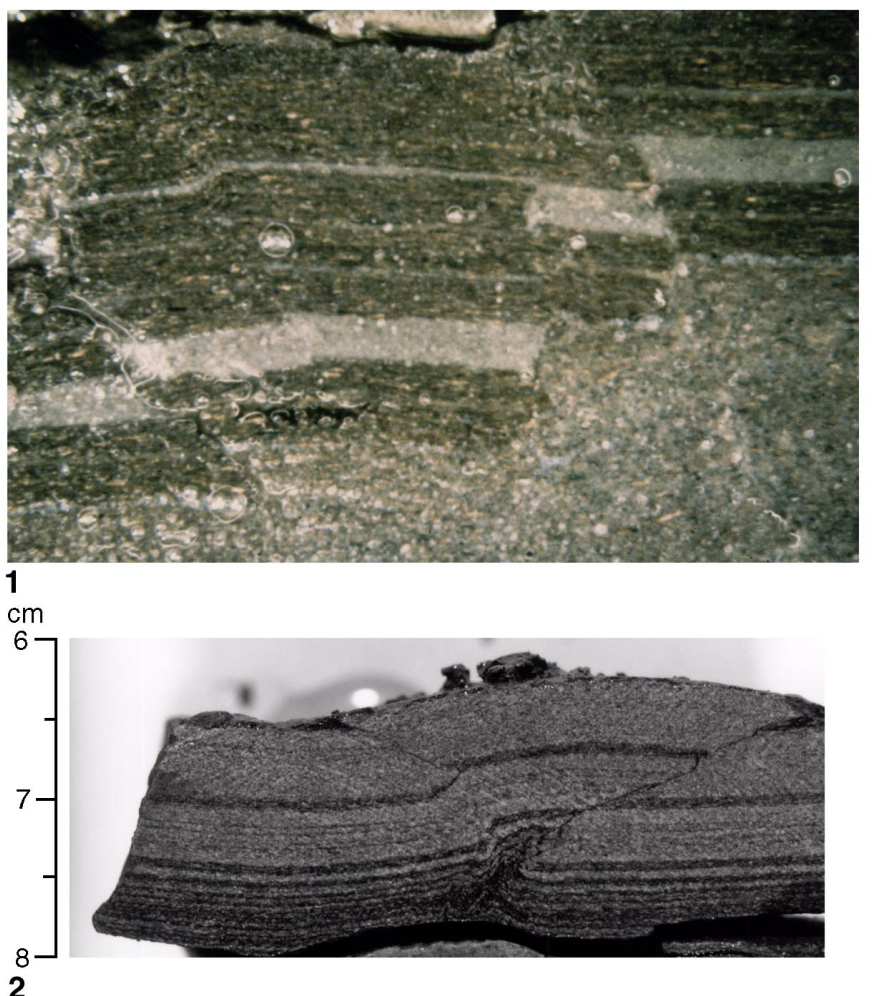

Plate 3. 1. Example of association between reverse faults and an asymmetric microfold. Note the deformed normal fault and the basal quartz microlayer (Sample 159-962D-12R-5, 87-90 cm). 2. Pop-up structure superimposed to previous extensional structures. Bounding faults are marked by thin seams of dark finegrained material (Sample 159-962D-27R-CC, 6-8 cm). 